\title{
Cardiac-Specific Overexpression of HIF- $1 \alpha$ Prevents Deterioration of Glycolytic Pathway and Cardiac Remodeling in Streptozotocin-Induced Diabetic Mice
}

\author{
Wanli Xue, ${ }^{\star \dagger \ddagger}$ Lu Cai, ${ }^{\dagger \S}{ }^{\dagger}$ Yi Tan, ${ }^{\dagger \S}$ \\ Patricia Thistlethwaite, ${ }^{\|}$Y. James Kang, ${ }^{\text {Tा }}$ \\ Xiaokun $\mathrm{Li}^{\dagger}{ }^{\dagger}$ and Wenke Feng ${ }^{\star \dagger}$ \\ From the Departments of Medicine, Pediatrics, ${ }^{\S}$ and \\ Pharmacology \& Toxicology, "Iniversity of Louisville School of \\ Medicine, Louisville, Kentucky; the Chinese-American Research \\ Institute for Diabetic Complications, ${ }^{\dagger}$ Wenzhou Medical College, \\ Wenzhou, Zhejiang, China; the Department of Public Health, ${ }^{*}$ \\ Xi'an Jiaotong University School of Medicine, Xi'an, Shaanxi, \\ China; and the Division of Cardiothoracic Surgery," University of \\ California, San Diego, San Diego, California
}

Defective glycolysis and angiogenesis in the heart of diabetic patients and in experimental diabetic animal models have been reported. The aim of this study was to determine whether overexpression of hypoxia-inducible factor (HIF)-1 $\alpha$ protects from myocardial injury in diabetic mice by increasing myocardial glycolysis and angiogenesis. Cardiac-specific HIF-1 $\alpha-$ overexpressing transgenic and age-matched wild-type control mice were treated with streptozotocin to induce diabetes. Changes in glucose transporters, glycolytic enzymes, angiogenic factors and cardiac morphology were examined in the hearts by real-time RT-PCR, Western blotting, enzymatic assay, and histological assays. HIF-1 $\alpha$ overexpression elevated hexokinase II (HK-II) protein level and total HK activity in nondiabetic heart and prevented the decreases in HK-II mRNA, protein, and total HK activity in diabetic heart. In addition, the reduction of glucose transporter I, but not glucose transporter 4, was restored in HIF transgenic mouse heart along with a recovery of myocardium ATP production. HIF-1 $\alpha$ overexpression also normalized diabetes-reduced vascular endothelial growth factor concentration along with a sustained myocardial capillary density and an inhibition of cardiomyocyte hypertrophy and cardiac fibrosis. Therefore, elevation of HIF-1 $\alpha$ provides a cardiac protection from diabetic-induced impairment in glucose metabolism and angiogenesis via up-regulation of
HIF-1 target genes. (Am J Patbol 2010, 177:97-105; DOI: 10.2353/ajpath.2010.091091)

Insulin-dependent diabetes mellitus induces a rapid reduction of glucose uptake and utilization and an inadequate neovascularization. Reduced glucose utilization in diabetic myocardium is associated with decreased activity of glucose transporter such as glucose transporter 1 (GLUT-1) and glycolysis enzymes, such as hexokinase II (HK-II). The insufficient blood vessel formation in diabetic heart is characterized by a significant reduction of vascular endothelial growth factor (VEGF) and its receptors, VEGFR1 (Flt-1) and VEGFR2 (Flk-1). ${ }^{1,2}$ HK-II overexpression increased ATP generation, leading to a cardiac protection from hypoxic or diabetic damage. ${ }^{3}$ VEGF gene delivery to myocardium showed an increase in capillary density, inhibition of apoptosis in endothelial cells and cardiomyocytes, and eventually improvement of cardiac function. ${ }^{4,5}$ However, it has been observed that VEGF is not sufficient as a single agent to create a functional vasculature, and VEGF alone-induced vessels are often leaky and do not properly connect to the existing vasculature. $^{6}$ It is therefore of interest to explore alternative approach to elicit the concomitant expression of multiple genes that are favorable for angiogenesis and glucose metabolism under diabetic conditions. Interestingly, studies have demonstrated that VEGF and its receptor-1, GLUT-1, and HK-II are the transcriptional targets of hypoxia-inducible factor-1(HIF-1) in various cell types.

Over the past decade, convincing evidence has shown that HIF-1 has an essential role in the maintenance of oxygen homeostasis in mammalian organisms. HIF-1 consists of two subunits, HIF- $1 \alpha$ and HIF- $1 \beta$. HIF- $1 \beta$ is

Supported in part by grants from the American Diabetes Association (07-07-JF-23 to W.F.; 02-07-JFA-10 and 05-07-CD-02 to L.C.), the National Institutes of Health (NIH HL63760 to Y.J.K.), and a grant from Chinese Natural Science Foundation (W.F.).

Accepted for publication March 24, 2010.

Address reprint requests to Wenke Feng, Ph.D., or Lu Cai, M.D., Ph.D., 505 S. Hancock St., CTR517, Louisville, KY 40202. E-mail: wenke.feng@|ouisville.edu or lu.cai@louisville.edu. 
Table 1. Sequences of Oligonucleotide Primers

\begin{tabular}{|c|c|c|c|}
\hline Gene names (mouse) & 5' oligonucleotide & 3' oligonucleotide & Size $(b p)$ \\
\hline$H I F-1 \alpha$ & $5^{\prime}-$ TCAAGTCAGCAACGTGGAAG-3' & 5'-TATCGAGGCTGTGTCGACTG-3' & 198 \\
\hline$H K-I I$ & 5'-CTGTCTACAAGAAACATCCCCATTT-3' & $5^{\prime}-$ CACCGCCGTCACCATAGC- $3^{\prime}$ & 134 \\
\hline$H K-I$ & $5^{\prime}-$ GACAAAGCGGTTCAAAGCCAG-3' & 5'-CGACTTCACACTGTTGGTCATCG-3' & 167 \\
\hline GLUT-1 & $5^{\prime}-$ CTAGAGCTTCGAGCGCAGCGCV & $5^{\prime}-$ AGGCCAACAGGTTCATCATC- $3^{\prime}$ & 335 \\
\hline GLUT-4 & $5^{\prime}$-CTGCTGCCCTTCTGTCCT-3' & $5^{\prime}-$ CGGTCAGGGGCTTTAGACT-3' & 91 \\
\hline VEGF & $5^{\prime}$-TTACTGCTGTACCTCCACC-3' & $5^{\prime}-$ ACAGGACGGCTTGAAGATG- $3^{\prime}$ & 189 \\
\hline Flk-1 & 5'-ACTGCAGTGATTGCCATGTTCT-3' & 5'-CCTTCATTGGCCCGCTTAA-3' & 74 \\
\hline$\beta-M H C$ & 5'-GTGCCAAGGGCCTGAATGAGV & $5^{\prime}$-GCAAAGGCTCCAGGTCTGA-3' & 84 \\
\hline$\alpha-M H C$ & $5^{\prime}$-AAGGTGAAGGCCTACAAGCG-3' & 5'-TTTCTGCTGGACAGGTTATTCC-3' & 205 \\
\hline $\mathrm{Ckm}$ & $5^{\prime}-$ ATCCGAAGTCGAACAGGTGC-3' & 5'-TGGCCCTTTTCCAGCTTCTT-3' & 81 \\
\hline$\beta$-actin & $5^{\prime}-$ GAGACCTTCAACACCCC-3' & $5^{\prime}$-ATAGCTCTTCTCCAGGGAGG-3' & 348 \\
\hline Transgene HIF-1 $\alpha$ & $5^{\prime}-$ GCAAGCCCTGAAAGCG-3' & $5^{\prime}$-GGCTGTCCGACTTTGA-3' & 240 \\
\hline
\end{tabular}

constitutively expressed, and $\mathrm{HIF}-1 \alpha$ is the regulatory subunit that senses tissue oxygen level and responds to various cellular stimuli, and up-regulates genes involved in the angiogenesis, glycolytic energy metabolism, cell proliferation, and survival. ${ }^{7,8}$ In addition to hypoxic stimulus, a variety of factors have been shown to be able to affect HIF-1 activity even under normoxic conditions. ${ }^{9-11}$ Hyperglycemia is the metabolic hallmark of diabetes, which has been shown to be a major cause of diabetic cardiomyopathy. Recent studies have also shown that hyperglycemia suppresses HIF- $1 \alpha$ protein stability, modification, and function. ${ }^{12-14}$ Studies attempting to increase HIF-1 activity have shown beneficial effects in preventing diabetic cardiomyopathy ${ }^{15}$ and in protecting diabetic heart from ischemic insult. ${ }^{16}$ The aim of this study was to examine whether or not constitutive elevation of HIF- $1 \alpha$ protects from myocardial injury in diabetic mice. The results demonstrated that cardiac-specific overexpression of HIF- $1 \alpha$ made the heart highly resistant to diabetes-induced injury by restoring VEGF, GLUT-1, and HK-II expression and activity. HIF-1 thus plays a critical role in regulating cardiac protective mechanism against diabetic pathogenesis.

\section{Materials and Methods}

\section{Experimental Animals}

The wild-type control CD1 mice were purchased from the Jackson Laboratory (Bar Harbor, ME). Cardiac-specific HIF- $1 \alpha$ overexpressing transgenic (HIF-TG) mice, which is driven by myosin heavy chain promoter, produced previously ${ }^{17}$ were backcrossed with CD1 mice for six generations and then used in present studies. The mice were housed in the University of Louisville Research Resources Center at $22^{\circ} \mathrm{C}$ with a 12-hour light/dark cycle and free access to rodent chow and tap water. All animal procedures were approved by the Institutional Animal Care and Use Committee, which is certified by the American Association for Accreditation of Laboratory Animals Care. Type-I diabetes mouse model was generated as described previously. ${ }^{18-20}$ In brief, eight-week-old male mice were intraperitoneally given a single dose of streptozotocin (STZ; Sigma-Aldrich, St. Louis, MO) at 150 $\mathrm{mg} / \mathrm{kg}$ body weight, dissolved in sodium citrate buffer
( $\mathrm{pH}$ 4.5). On day 3 after STZ treatment, fasting whole blood glucose obtained from mouse tail vein was detected using a SureStep complete blood glucose monitor (LifeScan, Milpitas, CA). STZ-treated mice with whole blood glucose higher than $250 \mathrm{mg} / \mathrm{dl}(13.9 \mathrm{mmol} / \mathrm{L})$ were considered as diabetic. Mice serving as vehicle controls were given the same volume of sodium citrate. Body weight and blood glucose level were measured regularly, and the mice were sacrificed at the experimental end points.

\section{Cell Culture and Glucose Metabolism}

H9c2 (a cardiac cell line derived from embryonic rat heart) cells were purchased from American Type of Cell Culture (Manassas, VA) and cultured in normal glucose (5.5 mmol/L, hereafter referred to as NG cells) or high glucose (25 mmol/L, hereafter referred to as HG cells) medium for 20 generations. Cells were then plated in 6 -well plates in DMEM containing $1 \%$ FBS as described $^{15,21}$ in the presence or absence of desferrioxamine (DFO, $100 \mu \mathrm{mol} / \mathrm{L}$ ) for 16 hours for induction of HIF$1 \alpha$. Glycolytic flux was determined by addition of $\left[5-{ }^{3} \mathrm{H}\right]$ glucose in the presence of $5.5 \mu \mathrm{mol} / \mathrm{L}$ glucose and measuring glycolysis generated- ${ }^{3} \mathrm{H}_{2} \mathrm{O}$ by scintillation counting as described previously. ${ }^{22,23}$

\section{Real-Time RT-PCR}

Total RNA from mouse hearts was isolated with TRIzol reagent (Invitrogen, Carlsbad, CA) according to the manufacturer's instructions. RNA was reverse-transcribed using reverse transcriptase (Applied Biosystems, Foster City, CA) with random hexamers, and PCR was performed using primers shown in Table 1. The relative quantities of target transcripts were calculated from duplicate samples after normalization of the data against housekeeping gene $\beta$-actin. Dissociation curve analysis was performed after PCR amplification to confirm the specificity of the primers. Relative mRNA expression was calculated using the $\delta \delta \mathrm{Ct}$ method. ${ }^{24}$

\section{Western Blot Analysis}

Protein preparations from heart tissues were obtained as described previously ${ }^{25,26}$ with modifications. Briefly, after 
removal, the hearts were immediately frozen in liquid nitrogen to minimize potential alteration in $\mathrm{HIF}-1 \alpha$ proteins. The samples were then stored at $-80^{\circ} \mathrm{C}$ for later use. The heart tissues were pulverized, and protein was extracted. Equal amounts of protein were subjected to $10 \%$ SDS-PAGE, followed by immunoblotting for VEGF, HK-II, HK-I, and $\beta$-actin using rabbit polyclonal antibodies specific for VEGF, HK-II and HK-I (1:200; Santa Cruz Biotechnology Inc., Santa Cruz, CA), and $\beta$-actin (1:1000; Santa Cruz) as described previously. ${ }^{25}$

\section{Preparation of Nuclear Fractions}

Nuclear fractions were prepared from heart tissues of wild-type and HIF-TG mice immediately after animals were sacrificed. Tissues were homogenized using a Polytron homogenizer in ice-cold $10 \mathrm{mmol} / \mathrm{L} \mathrm{Tris-HCl}(\mathrm{pH} 8.0)$ buffer containing $0.32 \mathrm{M}$ sucrose, $3 \mathrm{mmol} / \mathrm{L} \mathrm{CaCl}_{2}, 2$ $\mathrm{mmol} / \mathrm{L} \mathrm{MgCl}_{2}, 0.1 \mathrm{mmol} / \mathrm{L}$ EDTA, $0.5 \%$ Nonidet P-40, 1 $\mathrm{mmol} / \mathrm{L}$ dithiothreitol (DTT), $0.5 \mathrm{mmol} / \mathrm{L}$ phenylmethylsulphonyl fluoride (PMSF), 1\% protease inhibitor cocktail (Sigma). Homogenates were centrifuged at $800 \mathrm{~g}$ for 10 minutes. The pellets were washed two times with homogenization buffer without Nonidet P-40, then resuspended in low-salt buffer $(20 \mathrm{mmol} / \mathrm{L}$ HEPES, pH 7.9, $1.5 \mathrm{mmol} / \mathrm{L}$ $\mathrm{MgCl}_{2}, 20 \mathrm{mmol} / \mathrm{L} \mathrm{KCl}, 0.2 \mathrm{mmol} / \mathrm{L}$ EDTA, 25\% glycerol, $0.5 \mathrm{mmol} / \mathrm{L} \mathrm{DTT}$, and $0.5 \mathrm{mmol} / \mathrm{L} \mathrm{PMSF}$ ), incubated on ice for 5 minutes, and mixed with an equal volume of highsalt buffer (20 mmol/L HEPES, $1.5 \mathrm{mmol} / \mathrm{L} \mathrm{MgCl}_{2}, 800$ $\mathrm{mmol} / \mathrm{L} \mathrm{KCl}, 0.2 \mathrm{mmol} / \mathrm{L}$ EDTA, 25\% glycerol, $1 \%$ Nonidet P-40, $0.5 \mathrm{mmol} / \mathrm{L}$ DTT, $0.5 \mathrm{mmol} / \mathrm{L}$ PMSF, and $1 \%$ protease inhibitor cocktail). The mixtures were incubated on ice for 30 minutes, centrifuged at 14,000g for 15 minutes, and the supernatants were saved as nuclear fraction and stored at $-80^{\circ} \mathrm{C}$.

\section{Electrophoretic Mobility Shift Assay}

Electrophoretic mobility shift assay was performed using HIF-1 gel shift kit (Panomics, Redwood City, CA) according to the instruction provided by the manufacturer. Briefly, biotin-labeled double-stranded oligonucleotides containing the HIF-1 binding sequence from erythropoietin hypoxia responsive element (HRE) (5'-AGCTTGCCCTACGTGCTGTCTCAGA-3') was incubated with $5 \mu \mathrm{g}$ of nuclear extract and $1 \mu \mathrm{g}$ of poly $(\mathrm{dl}-\mathrm{dC}) \cdot(\mathrm{dl}-\mathrm{dC})$ in a buffer containing $10 \mathrm{mmol} / \mathrm{L}$ Tris- $\mathrm{HCl}, \mathrm{pH} 7.8,20 \mathrm{mmol} / \mathrm{L}$ $\mathrm{KCl}, 1 \mathrm{mmol} / \mathrm{L}$ EDTA, $5 \mathrm{mmol} / \mathrm{L}$ DTT, $1 \mathrm{mmol} / \mathrm{L} \mathrm{MgCl}_{2}$, and $5 \%$ glycerol at $4{ }^{\circ} \mathrm{C}$ for 30 minutes in a total volume of $15 \mu \mathrm{l}$. For competition assay, a 66-fold molar excess of unlabeled probe was added to the reaction before the addition of labeled probe. Electrophoresis was performed using $6 \%$ nondenaturing polyacrylamide gel at $120 \mathrm{~V}$ in $0.5 \times$ Tris-buffered EDTA for 1 hour at $4^{\circ} \mathrm{C}$. After transfer to a nylon membrane (Biodyne Plus; Pall, East Hills, NY), the reactants were immobilized by UV cross-linking. Biotinylated probe was detected using streptavidin-horseradish peroxidase and substrate reagents according to the manufacturer's recommendations (Panomics).

\section{Histopathology and Immunohistochemistry}

Hearts were excised, washed with saline solution, and placed in $10 \%$ formalin. Heart tissues were cut transversely close to the apex to visualize the left ventricles. Several sections of left ventricle ( $5 \mu \mathrm{m}$ thick) were prepared and stained with hematoxylin and eosin (H\&E) for histopathology or Sirius red (SR) for collagen deposition or fluorescein isothiocyanate-conjugated wheat germ agglutinin (WGA) for evaluation of myofiber size and visualized. The SR-stained sections were assessed for the proportion of fibrosis in the heart tissues by a computerassisted image analyzer (SigmaScan Pro5.0; SPSS, Inc. Chicago, IL). Ten fields at $\times 200$ magnification per heart were analyzed, and 3 to 7 mice in each group were examined for the calculation.

Immunohistochemical analysis of GLUT-1 and GLUT-4 was performed with rabbit antibody against mouse GLUT-1 (1:100; Santa Cruz) or GLUT-4 (1:100; Abcam, Cambridge, MA) and an anti-rabbit IgG (Vector, Burlingame, CA) as described previously. ${ }^{15}$

Cell area was quantified in WGA-stained left ventricle tissue sections by counting cell numbers in a random selected area in which at least 200 cells existed. Four areas per slide were selected, and three slides per group were analyzed.

Capillaries were visualized in frozen left ventricle sections stained with rat anti-mouse CD31 (BD Biosciences, San Diego, CA; 1:50) primary antibody and Cy3-labeled secondary antibodies (Abcam) using a fluorescence microscope. The capillary density was assessed by a computer-assisted image analysis system as described above for SR staining. Capillary density is expressed as number of capillaries per $\mathrm{mm}^{2}$.

\section{Assay of Hexokinase Activity}

Heart tissue hexokinase activity was determined by measuring the formation of coenzyme NADPH in a coupled enzyme assay system containing Glu-6-P dehydrogenase (Sigma) at room temperature as described previously. ${ }^{27} \mathrm{HK}$ activities were normalized to the protein content of the lysates. Protein concentrations were determined using the Bio-Rad protein assay kit with bovine serum albumin as a standard.

\section{Luciferase Reporter Assay}

HIF-1 HRE-dependent luciferase reporter activity in H9c2 cells was measured as previously described. ${ }^{15,25}$

\section{Myocardial ATP Levels}

ATP levels were quantified using the commercially available luciferin/luciferase bioluminescence assay system (Invitrogen). $10 \mathrm{mg}$ of heart tissues were homogenized on ice using a Dounce homogenizer in $1 \mathrm{ml}$ of precooled extractant $(0.1 \%$ trichloroacetic acid) and centrifuged at $4500 \mathrm{rpm}$ for 10 minutes. Supernatant $(100 \mu \mathrm{l})$ was diluted 10-fold with $50 \mathrm{mmol} / \mathrm{L}$ Tris-acetate buffer contain- 
ing $2 \mathrm{mmol} / \mathrm{L}$ ethylenediaminetetraacetic acid (pH 7.8). Then $10 \mu \mathrm{l}$ of sample or standard solution was placed in an assay tube followed by the injection of $100 \mu$ l of ATP luciferin/luciferase assay mix for ATP quantification. Luminescence was measured at a set of lag time of 1 second and integration time of 10 seconds. ATP contents were normalized to the protein content and expressed as nmole per mg protein.

\section{Statistical Analysis}

Data were expressed as mean \pm SE. Comparison between groups was performed using one-way analysis of variance followed by least significant difference post hoc test. Differences were considered significant at $P<0.05$.

\section{Results}

\section{STZ-Induced Diabetes Model in HIF-TG Mice}

Wild-type mice treated with STZ showed consistent fasting high blood glucose levels (>13.9 mmol/L) in entire experimental period. HIF- $1 \alpha$ overexpressing did not affect blood glucose levels in diabetes (Figure 1A). Realtime RT-PCR analysis showed the expression of HIF- $1 \alpha$ transgene in both nondiabetic and diabetic HIF-TG hearts (Figure 1B), and endogenous HIF-1 $\alpha$ mRNA showed no change in diabetic wild-type mouse heart and a significant increase in diabetic HIF-TG hearts compared with that in control hearts (Figure 1C). Gel mobility shift assay demonstrated an increase of DNA binding activity in HIF-TG cardiac nuclear extract under diabetic conditions (Figure 1D).

\section{HIF-1 $\alpha$ Overexpression Attenuates \\ Diabetes-Suppressed Hexokinase II}

We examined the effect of HIF- $1 \alpha$ on protein and mRNA levels of HK-II and HK-I, the first enzymes in glycolysis catalyzing glucose phosphorylation. HIF-1 $\alpha$ overexpression increased HK-II protein level in nondiabetic control heart and normalized the diabetes-reduced HK-II protein expression (Figure 2A). Under nondiabetic control conditions, HIF- $1 \alpha$ overexpression did not change the HK-II mRNA. However, under diabetic conditions, HIF- $1 \alpha$ overexpression completely relieved diabetes-induced reduction in HK-II mRNA levels (Figure 2B, left). We also examined HK-I mRNA and protein levels. Diabetes reduced HK-I mRNA but not protein level (Figure 2B, right). HIF-1 $\alpha$ overexpression did not change HK-I protein expression under either diabetic or nondiabetic conditions (Figure 2A). Overall, HIF- $1 \alpha$ overexpression did not increase HK activity in nondiabetic heart but prevented the decrease induced by diabetic conditions (Figure 2C).

\section{HIF-1 $\alpha$ Overexpression Attenuates Diabetes-Suppressed GLUT-1}

We next determined mRNA levels of glucose transporter GLUT-1 and GLUT-4. Diabetes decreased GLUT-1
A
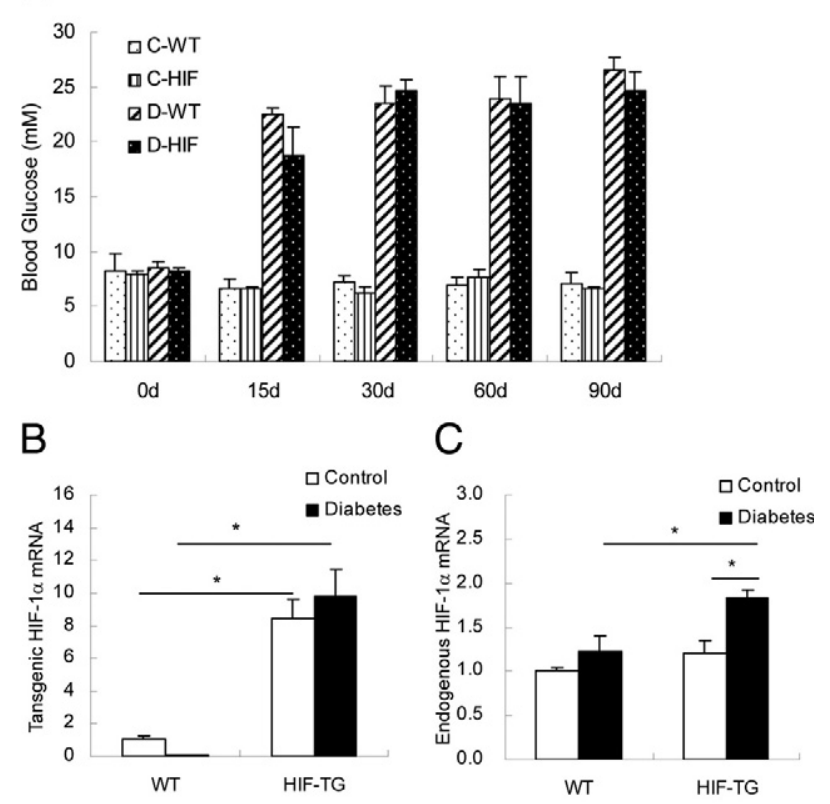

$\mathrm{D}$

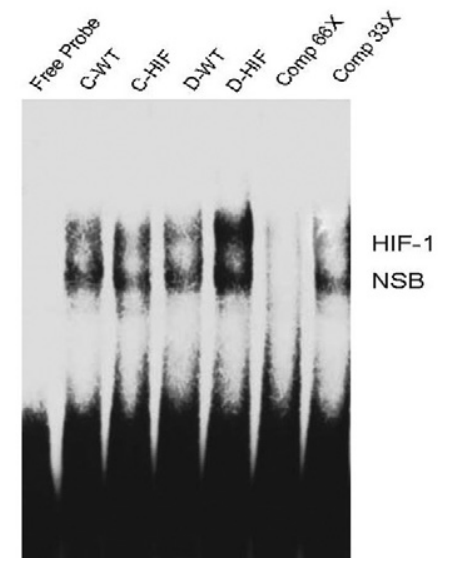

Figure 1. Induction of diabetes in mice. A: Effect of STZ on blood glucose levels. Fasting blood glucose levels of 8-week-old wild-type and HIF-TG mice treated with $150 \mathrm{mg} / \mathrm{kg} \mathrm{STZ}$ or sodium citrate buffer were measured every 15 or 30 days for 90 days. Real-time RT-PCR analysis of human (B transgene) and mouse (C, endogenous) HIF- $1 \alpha$ mRNA expression in control and diabetic hearts. The relative expression was normalized to that of $\beta$-actin calculated using the comparative threshold cycle method of $2^{-\delta \delta \mathrm{CT}}$. ${ }^{*} P<0.05$. D: Electrophoretic mobility shift assay (EMSA) analysis of HRE binding activity. Nuclear extracts were prepared and analyzed by EMSA for HRE binding to a biotin-labeled HRE containing the HIF-1 binding site of the erythropoietin 3 ' enhancer. The presence of HIF-1 was verified in a competition assay by adding 66- and 33-fold molar excess of unlabeled oligonucleotides to the binding reaction before the addition of labeled probe. Each group contained four to seven animals in all experiments. C-WT, wild-type control; C-HIF, HIF-1 $\alpha$ transgenic control; D-WT, wild-type diabetes; D-HIF, HIF- $1 \alpha$ transgenic diabetes; NSB, nonspecific binding. These abbreviations are also used in the following figures.

mRNA level in wild-type heart. HIF-1 $\alpha$ overexpression markedly increased GLUT-1 mRNA in nondiabetic heart and normalized diabetic-reduced expression (Figure 3A, left). In addition, the mRNA level of another major glucose transporter, GLUT-4, was significantly reduced in wildtype diabetic heart. However, HIF-1 $\alpha$ overexpression had no effect on GLUT-4 level under both nondiabetic and diabetic conditions (Figure $3 \mathrm{~A}$, right). Parallel with mRNA levels, diabetes caused a reduction of GLUT-1 and GLUT-4 proteins in wild-type heart. HIF-1 $\alpha$ overexpres- 
A

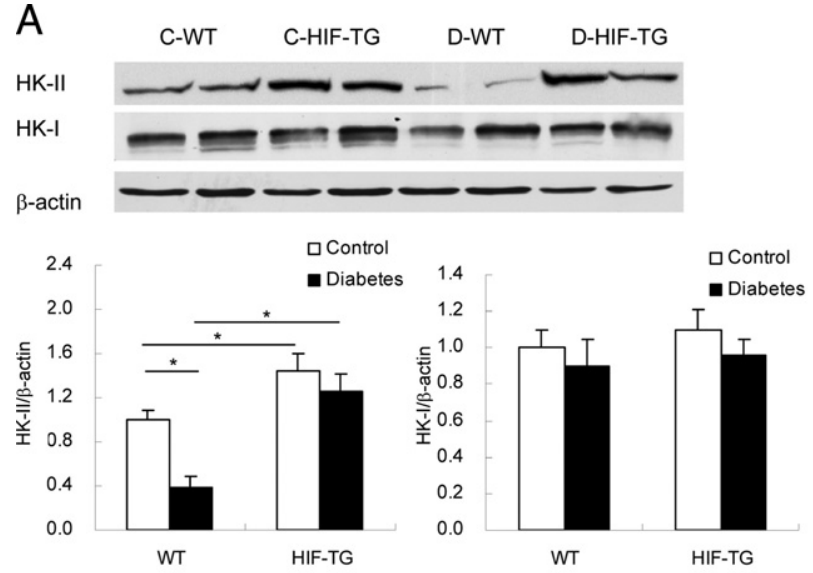

B
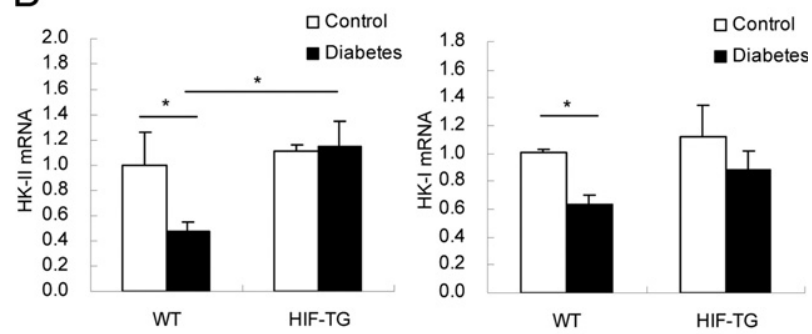

C

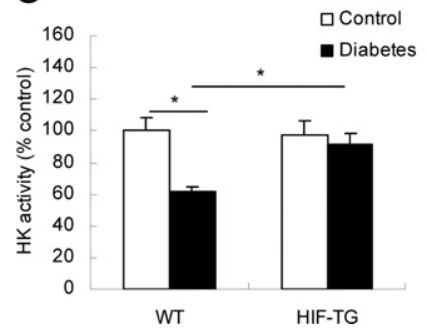

Figure 2. Effects of HIF-1 $\alpha$ on HK-II. A: Western blot analysis and semiquantitative analysis of HK-II and HK-I in total tissue extracts of control and diabetic mice (two months). The optical density of protein bands were normalized to that of $\beta$-actin. B: Real-time RT-PCR analysis of HK-II and HK-I mRNA expression in control and diabetic mice (two months). C: HK activities were determined by measuring the formation of coenzyme NADPH in a coupled enzyme assay system containing Glu-6-P dehydrogenase and normalized by the protein content of the sample (two months diabetes). ${ }^{*} P<$ 0.05 .

sion largely restored GLUT-1 but not GLUT-4 protein level in both control and diabetic hearts (Figure 3B) assessed by immunohistochemical analysis of cardiac tissue cross-sections.

\section{Effect of HIF-1 $\alpha$ Overexpression on Myocardial ATP Production}

HIF-1 $\alpha$ overexpression did not change ATP content under nondiabetic conditions but significantly prevented the reduction of ATP by diabetic conditions (Figure 4A). We further determined the muscle creatine kinase mRNA levels in the heart tissues. A significant reduction of muscle creatine kinase mRNA was observed in wild-type diabetic heart but not in HIF-TG diabetic heart (Figure 4B).
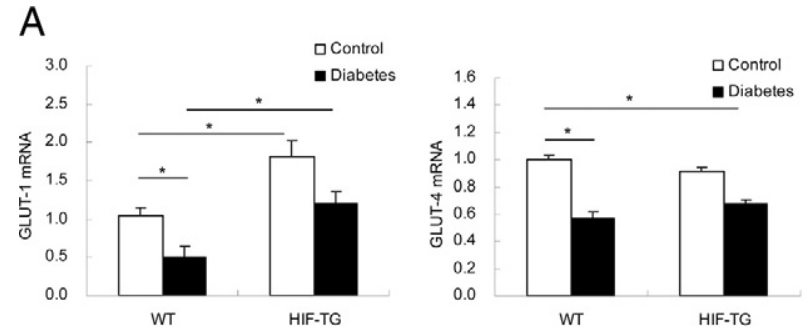

B GLUT-1
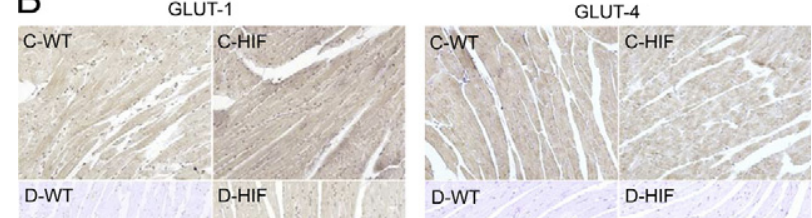

50um

Figure 3. Effects of HIF- $1 \alpha$ on GLUT-1 and GLUT- 4 expression. mRNA levels by real time RT-PCR (A) and protein levels by immunohistochemical analysis (B) of GLUT-1 and GLUT-4 of 2-month diabetic or control hearts. Sections were counterstained with hematoxylin. Original magnification: $\times 200$. Bars $=50 \mu \mathrm{m} .{ }^{*} P<0.05$.

\section{Effect of HIF-1 $\alpha$ Induction on Glucose Metabolism}

To determine the effect of HIF-1 $1 \alpha$ on glucose metabolism, we used rat heart derived $\mathrm{H} 9 \mathrm{c} 2$ cells subcultured for 20 generations in normal glucose $(5.5 \mathrm{mmol} / \mathrm{L}, \mathrm{NG})$ or high
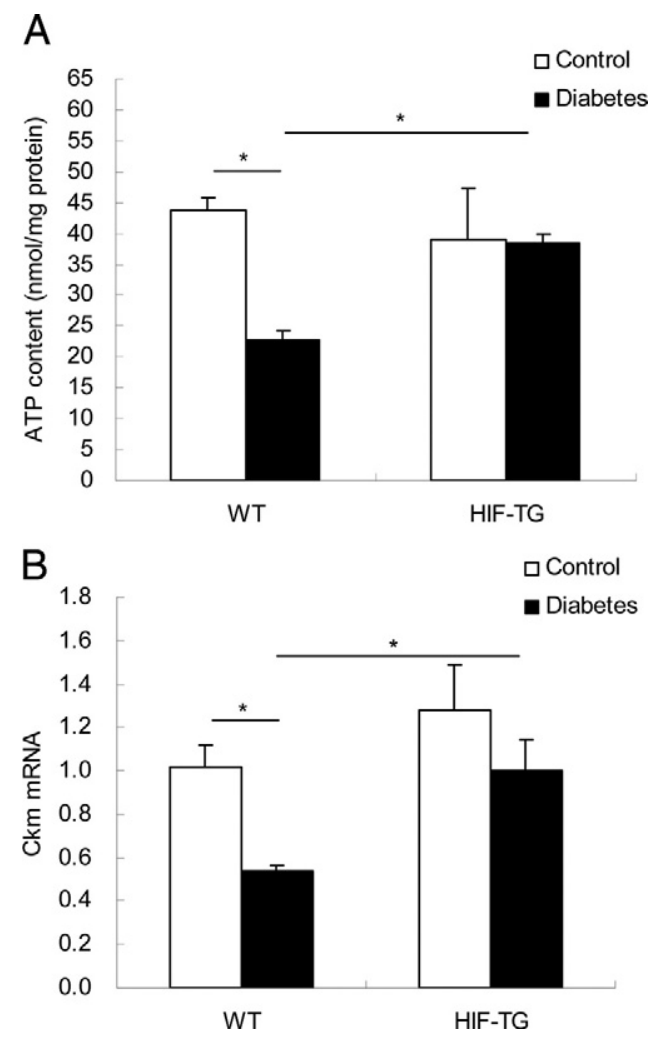

Figure 4. Effects of HIF- $1 \alpha$ on cardiac ATP. A: ATP contents in 2-month diabetic and control heart tissues were quantified by a luciferase based assay. B: Muscle creatine kinase $(\mathrm{Ckm})$ mRNA level by real-time RT-PCR. ${ }^{*} P<0.05$. 
A

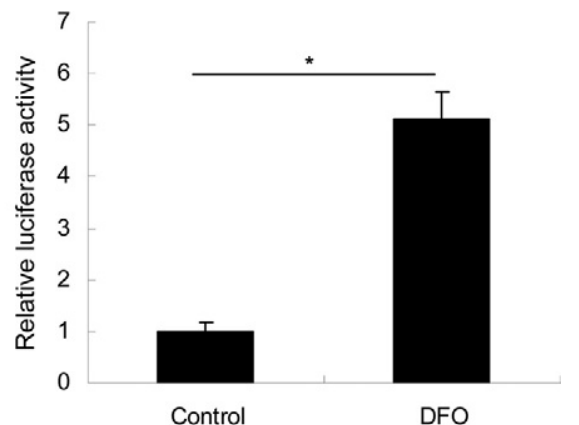

B

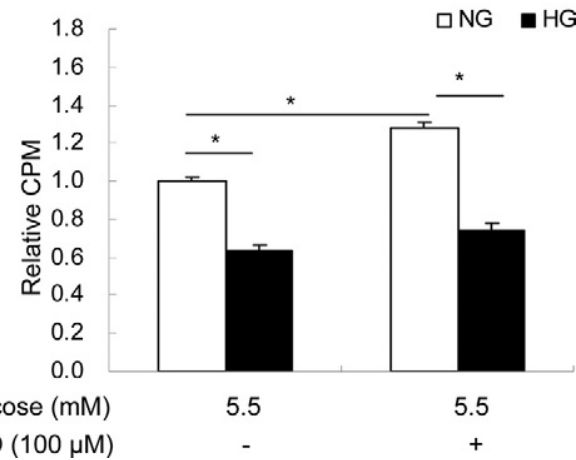

Figure 5. Effects of HIF-1 induction on glucose metabolism. A: H9c2 cells were cultured in $5.5 \mathrm{mmol} / \mathrm{L}$ glucose containing media and transfected with HIF-1 reporter luciferase plasmid. Cells were treated with $100 \mu \mathrm{mol} / \mathrm{L}$ DFO for 16 hours, and luciferase activities were measured and normalized to sample protein concentration. ${ }^{*} P<0.05$. B: Normal glucose $(\mathrm{NG})$ and high glucose (HG)-cultured $\mathrm{H} 9 \mathrm{c} 2$ cells were incubated in the presence or absence of $100 \mu \mathrm{mol} / \mathrm{L}$ DFO for 16 hours. Control and DFO-treated cells were incubated with $\left[5-{ }^{3} \mathrm{H}\right]$ glucose in the presence of $5.5 \mathrm{mmol} / \mathrm{L}$ glucose for three hours. Glycolysis-produced ${ }^{3} \mathrm{H}_{2} \mathrm{O}$ was measured by scintillation counting and normalized to cell number. ${ }^{*} P<0.05$.

glucose $(25 \mathrm{mmol} / \mathrm{L}, \mathrm{HG})$ containing media. Glycolysis was measured in the presence or absence of DFO, a well-known agent to induce $\mathrm{HIF}-1 \alpha$ accumulation. ${ }^{28}$ Treatment with DFO induced a marked elevation of HIF-1 transcriptional activity assessed by HRE-dependent luciferase assay (Figure 5A) and significantly increased glycolysis (Figure 5B) in $\mathrm{H} 9 \mathrm{c} 2$ cells cultured consistently under either $\mathrm{NG}$ or $\mathrm{HG}$ conditions. Importantly, long term incubation of cells under $H G$ conditions impaired both basal and DFO-induced glycolysis (Figure 5B).

\section{HIF-1 $\alpha$ Overexpression Restores VEGF Levels and Preserves Angiogenesis in Diabetic Heart}

HIF- $1 \alpha$ overexpression did not change the capillary density under nondiabetic conditions but significantly prevented the diabetes-induced reduction (Figure 6A). To determine whether this alteration is associated with changes in proangiogenic factors, we measured the levels of VEGF and its receptors. A $55 \%$ reduction in the mean mRNA expression and $44 \%$ reduction in the mean VEGF protein levels were observed in wild-type heart 2 months after diabetic onset compared with nondiabetic controls, and HIF- $1 \alpha$ overexpression restored VEGF expression in both mRNA and protein levels (Figure 6, B and $\mathrm{C}$ ). Further analysis revealed a significant prevention of the reduction of Flk-1 mRNA by diabetes in
A
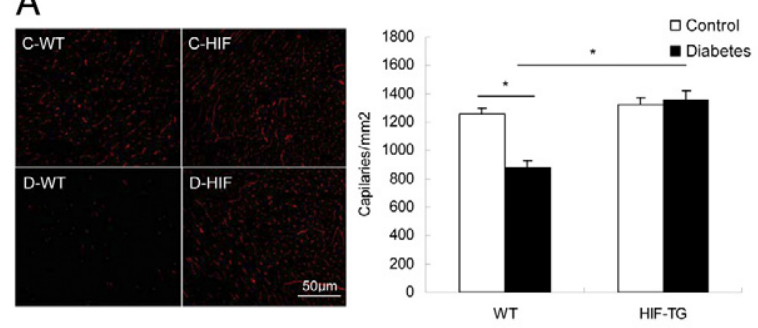

B
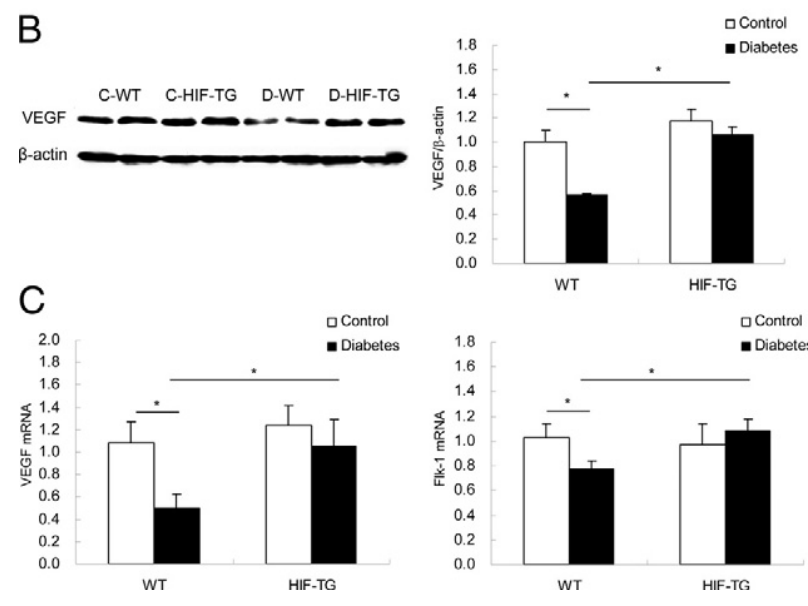

Figure 6. HIF- $1 \alpha$ restores diabetes-suppressed VEGF expression and capillary density. A: Capillary density in 2-month diabetic and control heart tissues was accessed by CD31 staining (left) and quantification of capillary numbers per $\mathrm{mm}^{2}$ (right). Original magnification: $\times 200$. Bars $=50 \mu \mathrm{m}$. B: VEGF expression was assessed by Western blot analysis (left) and densitometry quantification (right) normalized to that of $\beta$-actin. C: Real-time RT-PCR analysis of VEGF and Flk-1 mRNA expression in control and diabetic mice. ${ }^{*} P<0.05$.

HIF-TG heart. Same change, however, was not found for VEGFR-1 (FIt-1; data not shown).

\section{Protection of Cardiac-Specific HIF-1 $\alpha$ Overexpression Against Diabetes-Induced Cardiac Remodeling}

Histological examinations revealed significant differences in histopathological changes in the heart between the wild-type and HIF-TG diabetic mice. Disorganized array of the myocardial structure, cell necrosis, and myofibrillar discontinuation were observed in the heart of wild-type diabetic mice but not in the heart of control or HIF-TG diabetic mice, as shown in Figure 7A. Cardiac fibrosis was observed in diabetic wild-type mice, but not in HIF-TG mice, as assessed by SR staining of collagen (Figure 7, A and B). In nondiabetic wild-type and HIF-TG mice, the body weight (BW), heart weight (HW). and HW/BW parameters were not significantly changed. Diabetes caused a significant loss in BW and HW and slight increase in HW/BW ratio in wild-type mice. HIF- $1 \alpha$ overexpression in diabetic mice improved the BW and HW and significantly reduced HW/BW compared with diabetic wild-type mice (Table 2). WGA staining of cardiomyocytes in left ventricle tissue sections showed cellular enlargement in wild-type diabetic heart but not in HIF-TG heart (Figure $7 \mathrm{C}$ ). $\beta$-myosin heavy chain $(\beta$-MHC) has been used as a hypertrophy marker and can be induced 

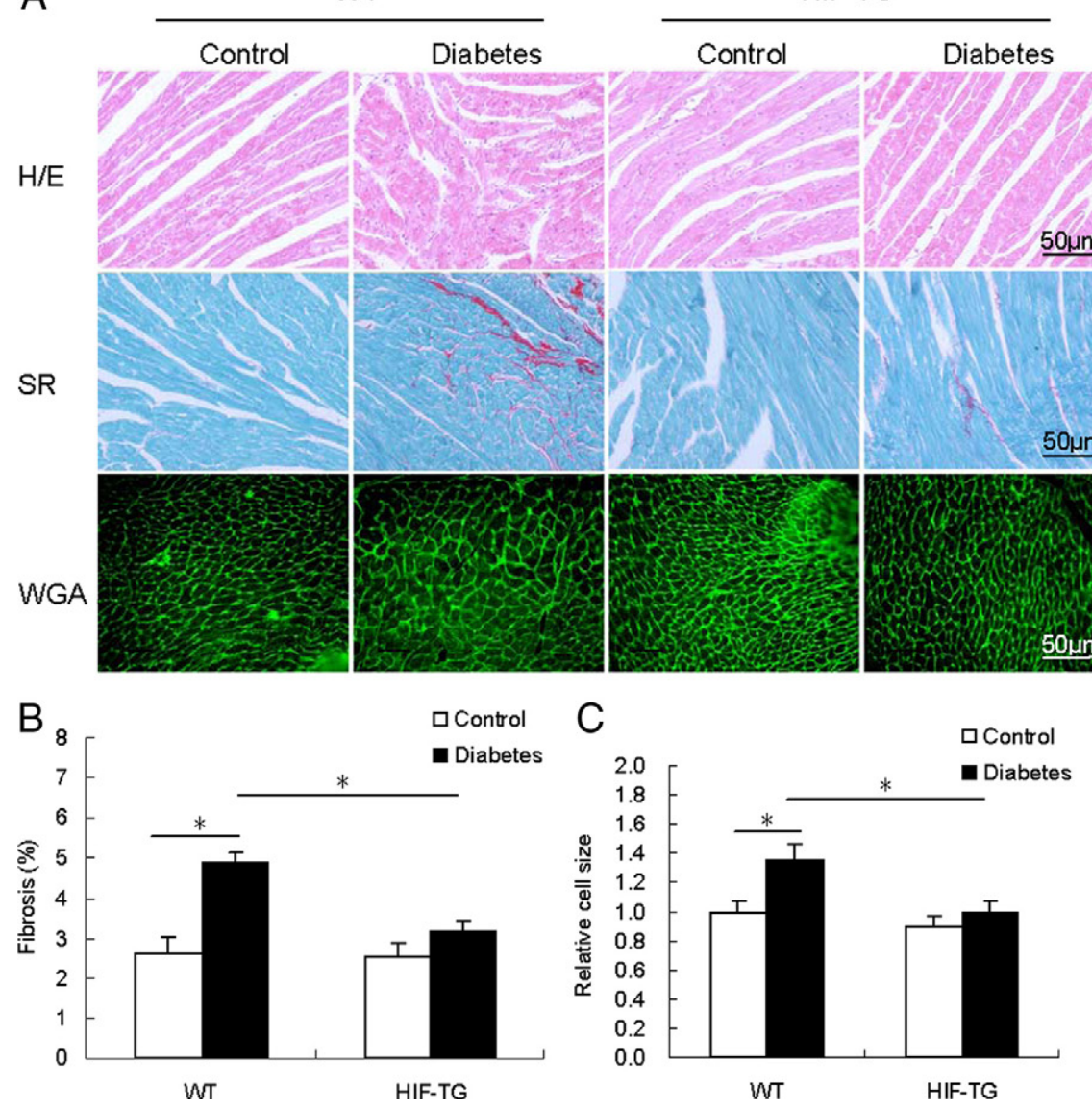

Figure 7. HIF- $1 \alpha$ overexpression prevents myocardial injury in diabetic mice. A: Cardiac morphology changes in 2-month diabetic and control heart tissues were observed by cross section: Histopathological changes by hematoxylin and eosin (H\&E) staining, fibrosis by Sirius red (SR), and cell size by wheat germ agglutinin (WGA) staining for cell membrane. Original magnification, $\times 200$. Scale bars $=50 \mu \mathrm{m}(\mathrm{H} \& \mathrm{E}$, SR, and WGA panels). B: Quantification of fibrosis was presented by the proportion of fibrotic area in the whole heart. C: Relative cardiomyocyte size. D: Ratio of mRNA levels of $\beta$-MHC to $\alpha$-MHC. ${ }^{*} P<0.05$.

in diabetic heart in the absence of hypertrophy. Diabetes induced marked increase of $\beta-\mathrm{MHC} / \alpha-\mathrm{MHC}$ mRNA ratio in wild-type heart and this increase was significantly suppressed in HIF-TG mouse heart (Figure 7D).

\section{Discussion}

The major finding of this study is that cardiac-specific overexpression of $\mathrm{HIF}-1 \alpha$ leads to cardioprotection in diabetic mice induced by STZ. We showed that HIF-1 $\alpha$ overexpression relieved the suppression of GLUT-1 and HK-II by diabetes leading to a recovery in ATP production and restored VEGF expression level along with a sustained capillary density in diabetic heart.

$\mathrm{HIF-1}$ is a master transcription factor; it regulates more than three hundred genes involved in many cellular processes including angiogenesis, glucose metabolism, cell survival, and oxygen delivery. HIF-1 confers protection

Table 2. Body Weight and Heart Weight

\begin{tabular}{lccl}
\hline & $\begin{array}{c}\text { Body } \\
\text { weight }(\mathrm{g})\end{array}$ & $\begin{array}{c}\text { Heart } \\
\text { weight }(\mathrm{mg})\end{array}$ & HW/BW ratio \\
\hline C-WT & $31.53 \pm 2.52$ & $126.50 \pm 5.50$ & $3.78 \pm 0.41$ \\
C-HIF & $33.20 \pm 3.78$ & $124.33 \pm 6.44$ & $3.80 \pm 0.27$ \\
D-WT & $22.07 \pm 2.05^{\star}$ & $94.57 \pm 8.38^{*}$ & $4.33 \pm 0.13$ \\
D-HIF & $31.06 \pm 2.92^{\star *}$ & $109.40 \pm 7.44$ & $3.58 \pm 0.23^{\star *}$ \\
\hline
\end{tabular}

${ }^{\star} P<0.05$ versus $\mathrm{C}-\mathrm{WT} ;{ }^{* *} P<0.05$ versus $\mathrm{D}-\mathrm{WT}$. ischemic injury by triggering the activation of specific protective genes. Genetic overexpression of HIF- $1 \alpha$ reduced infarction area in ischemic heart. Stabilization of HIF- $1 \alpha$ by inhibition of prolyl hydoxylase or by treatment of $\mathrm{CoCl}_{2}$ produced a decrease in infarct size and cardiac dysfunction after global ischemia/reperfusion. Global deletion of $\mathrm{HIF-1} \alpha$ results in embryonic lethality with increased thickness of the embryonic heart. ${ }^{29,30}$ Cardiac myocyte-specific HIF-1 $\alpha$ deletion alters vascularization, energy availability, calcium flux, and contractility even in the normoxic heart. ${ }^{31}$ It has been demonstrated that hyperglycemia reduced HIF-1 $\alpha$ expression leading to myocardial injury. However, whether elevation of HIF-1 $\alpha$ preserves HIF-1 activity in diabetic heart has not yet been defined. Using cardiac-specific HIF-1 $\alpha$ overexpressing mouse model, the present study demonstrated that $\mathrm{HIF}-1 \alpha$ transgene increased both human $\mathrm{HIF}-1 \alpha$ and endogenous mouse HIF- $1 \alpha$ mRNA and increased HIF-1 DNA binding activity under diabetic conditions.

In the absence of insulin, glucose transport into cardiomyocytes limits the rate of glucose utilization. Cardiac muscle cells express two distinct glucose transporters. Although GLUT-4 is insulin-dependent and is quantitatively the important glucose transporter expressed in heart, the insulin-independent GLUT-1 is also expressed at a substantial level. In STZ-diabetic mice, insulin deficiency reduces GLUT-4 membrane localization and thus 
impairs its function. Therefore, GLUT- 1 becomes important in glucose transport in STZ-heart when insulin level and sensitivity are not corrected. Previous reports have shown that the expression of GLUT-1 and GLUT-4 are reduced in diabetic heart, ${ }^{32}$ which leads to a reduced cardiac glucose influx in diabetic patients. ${ }^{33,34}$ Consistent with previous studies, we found that STZ-induced diabetes significantly reduced both GLUT-1 and GLUT-4 mRNA and protein expression in the heart. Importantly, HIF-1 $\alpha$ overexpression significantly increased the basal level of GLUT-1 but not GLUT-4 mRNA and protein in nondiabetes controls. In diabetic heart, GLUT-1, but not GLUT-4, was normalized to nondiabetic control level. This differential regulation of HIF-1 on the two glucose transporters reflects the transcriptional modulation by HIF- $1 \alpha$ in glucose transport; GLUT-1, not GLUT-4, is one of the HIF-1 target genes.

In addition to glucose transporters, HK plays an important role in cellular glucose metabolism by converting glucose to glucose-6-phosphate, thus maintaining the downhill glucose concentration gradient necessary to move glucose further into the cells. HK has four major isoforms, and HK-II is the predominant isoform in the heart. The expression of HK-II is partially regulated by HIF-1. ${ }^{35}$ Diabetic heart shows reduced HK-II ${ }^{36}$ together with reduction of glucose transporters and other glycolytic enzymes leading to a reduced cardiac glucose usage in diabetic patients. ${ }^{33,34}$ Reduction of glucose metabolism is believed to be a mechanism in diabetic cardiomyopathy, ${ }^{37}$ and restoration of cardiac glucose metabolism improves diabetic heart function. We found that HIF- $1 \alpha$ overexpression increased HK-II along with restored HK activity in diabetic heart suggesting an important role of HIF- $1 \alpha$ in glucose metabolism in diabetic heart. This notion was further demonstrated by an in vitro assessment of glycolysis in cardiac cells.

Studies have shown that diabetic hearts have very low ATP content ${ }^{3,38}$ and impaired contractility. ${ }^{39,40}$ HK-II overexpression improves cellular ATP content in diabetic cardiomyocytes and cellular function. ${ }^{3}$ In this study, we found that HIF- $1 \alpha$ overexpression markedly restored the diabetes-reduced ATP content in the heart suggesting a critical role of $\mathrm{HIF}-1 \alpha$ in energy production in diabetic heart. The role of HIF- $1 \alpha$ in ATP production is further demonstrated by muscle creatine kinase analysis, whose enzymatic product-phosphocreatine serves as an energy reservoir for the rapid buffering and regeneration of ATP. A significant relief of the diabetes-reduced creatine kinase mRNA level in HIF-TG heart was observed.

Another important finding is that $\mathrm{HIF-1} \alpha$ overexpression is able to restore the diabetes-reduced VEGF level leading to a normalization of capillary density. Inadequate angiogenesis has been shown as a major cellular and metabolic response in diabetic cardiomyopathy. VEGF is a major mediator of neovascularization in physiological and pathophysiological conditions by promoting blood vessel formation. The effects of diabetes and insulin-resistant states on cardiac and cardiovascular expression of VEGF were not known until recent studies. Chou et $\mathrm{al}^{1}$ have shown that the expression of mRNA and protein of VEGF and its receptors Flt-1 and Flk-1 in the myocar- dium was decreased significantly in both diabetic and insulin-resistant nondiabetic rats, as well as in diabetic patients. The down-regulation of myocardial VEGF expression preceded all other features of diabetic cardiomyopathy and was followed by an increased apoptosis of endothelial cells, decreased numbers of circulating endothelial progenitor cells, decreased capillary density, and impaired myocardial perfusion. In addition, ATP has been shown to be a proangiogenic factor because of its ability to potentiate the effects of both VEGF and basic fibroblast growth factor. Thus, elevation of myocardial ATP concentration in HIF- $1 \alpha$ transgenic heart provides secondary protection in angiogenisis under diabetes conditions.

Increasing VEGF expression is beneficial for preventing cardiac hypertrophy and fibrosis under diabetic conditions. In physiological hypertrophy, growth signals simultaneously induce hypertrophy and VEGF expression and thus maintain the balance between angiogenesis and myocytes hypertrophy. ${ }^{41,42}$ Impaired myocardial VEGF expression in the pathological hypertrophy results in vascular reduction and promotes the transition of hypertrophy to heart failure. Our previous studies also showed that increasing myocardial VEGF by copper supplementation reduced cardiac hypertrophy and myocardial fibrosis induced by pressure-overload in mice, which is mediated by HIF- $1 \alpha$ activation. ${ }^{43}$ VEGF treatment of primary neonatal rat cardiomyocytes reduced phenylephrine-induced cell hypertrophy. ${ }^{44}$ The data presented in the current study show that the prevention of cardiac myocyte hypertrophy and fibrosis by HIF- $1 \alpha$ underscores a critical role of $\mathrm{HIF}-1 \alpha$ in transcriptional regulation of VEGF in cardiac remodeling in diabetic heart.

In summary, the current study brought new evidence that $\mathrm{HIF}-1 \alpha$ constitutive overexpression protects heart from diabetic-induced impairment in angiogenesis and glucose metabolism. The potential strategy of activation HIF-1 for treatment of diabetic heart diseases might be superior to individual gene manipulation because HIF-1 can provide a variety of necessary factors for angiogenesis and glucose metabolism. This is particularly important when diabetic heart undergoes ischemic insults in which HIF-1 activation is required for an adaptive response. The precise mechanisms and the clinical use of HIF- $1 \alpha$ as a therapeutic target in diabetic complications deserve further in-depth investigation.

\section{References}

1. Chou E, Suzuma I, Way KJ, Opland D, Clermont AC, Naruse K, Suzuma K, Bowling NL, Vlahos CJ, Aiello LP, King GL: Decreased cardiac expression of vascular endothelial growth factor and its receptors in insulin-resistant and diabetic States: a possible explanation for impaired collateral formation in cardiac tissue. Circulation 2002, 105:373-379

2. Rodrigues B, Cam MC, McNeill JH: Metabolic disturbances in diabetic cardiomyopathy. Mol Cell Biochem 1998, 180:53-57

3. Ye G, Donthi RV, Metreveli NS, Epstein PN: Overexpression of hexokinase protects hypoxic and diabetic cardiomyocytes by increasing ATP generation. Cardiovasc Toxicol 2005, 5:293-300

4. Yoon Ys, Uchida S, Masuo O, Cejna M, Park JS, Gwon Hc, Kirchmair R, Bahlman F, Walter D, Curry C, Hanley A, Isner JM, Losordo DW: Progressive attenuation of myocardial vascular endothelial growth 
factor expression is a seminal event in diabetic cardiomyopathy: restoration of microvascular homeostasis and recovery of cardiac function in diabetic cardiomyopathy after replenishment of local vascular endothelial growth factor. Circulation 2005, 111:2073-2085

5. Rivard A, Silver M, Chen D, Kearney M, Magner M, Annex B, Peters $\mathrm{K}$, Isner JM: Rescue of diabetes-related impairment of angiogenesis by intramuscular gene therapy with adeno-VEGF. Am J Pathol 1999 154:355-363

6. Carmeliet P: VEGF gene therapy: stimulating angiogenesis or angioma-genesis? Nat Med 2000, 6:1102-1103

7. Semenza GL, Jiang BH, Leung SW, Passantino R, Concordet JP, Maire P, Giallongo A: Hypoxia response elements in the aldolase A, enolase 1 , and lactate dehydrogenase $A$ gene promoters contain essential binding sites for hypoxia-inducible factor 1. J Biol Chem 1996, 271:32529-32537

8. Semenza GL, Shimoda LA, Prabhakar NR: Regulation of gene expression by HIF-1. Novartis Found Symp 2006, 272:2-8

9. Feldser D, Agani F, Iyer NV, Pak B, Ferreira G, Semenza GL: Reciprocal positive regulation of hypoxia-inducible factor 1alpha and insulin-like growth factor 2. Cancer Res 1999, 59:3915-3918

10. Gleadle JM, Ebert BL, Firth JD, Ratcliffe PJ: Regulation of angiogenic growth factor expression by hypoxia, transition metals, and chelating agents. Am J Physiol 1995, 268:C1362-C1368

11. Treins C, Giorgetti-Peraldi S, Murdaca J, Van Obberghen E: Regulation of vascular endothelial growth factor expression by advanced glycation end products. J Biol Chem 2001, 276:43836-43841

12. Catrina SB, Okamoto K, Pereira T, Brismar K, Poellinger L: Hyperglycemia regulates hypoxia-inducible factor-1alpha protein stability and function. Diabetes 2004, 53:3226-3232

13. Gao W, Ferguson G, Connell P, Walshe T, Murphy R, Birney YA, O'Brien C, Cahill PA: High glucose concentrations alter hypoxiainduced control of vascular smooth muscle cell growth via a HIF1[alpha]-dependent pathway. J Mol Cell Cardiol 2007, 42:609-619

14. Ceradini DJ, Yao D, Grogan RH, Callaghan MJ, Edelstein D, Brownlee M, Gurtner GC: Decreasing intracellular superoxide corrects defective ischemia-induced new vessel formation in diabetic mice. J Biol Chem 2008, 283:10930-10938

15. Feng W, Wang Y, Cai L, Kang YJ: Metallothionein rescues hypoxiainducible factor-1 transcriptional activity in cardiomyocytes under diabetic conditions. Biochem Biophys Res Commun 2007, 360: 286-289

16. Chen JX, Stinnett A: Ang-1 gene herapy inhibits hypoxia-inducible factor-1\{alpha\} (HIF-1\{alpha\})-prolyl-4-hydroxylase-2, stabilizes HIF1 alpha\} expression, and normalizes immature vasculature in $\mathrm{db} / \mathrm{db}$ mice. Diabetes 2008, 57:3335-3343

17. Kido M, Du L, Sullivan CC, Li X, Deutsch R, Jamieson SW, Thistlethwaite PA: Hypoxia-inducible factor 1-alpha reduces infarction and attenuates progression of cardiac dysfunction after myocardial infarction in the mouse. J Am Coll Cardiol 2005, 46:2116-2124

18. Cai L, Wang J, Li Y, Sun X, Wang L, Zhou Z, Kang YJ: Inhibition of superoxide generation and associated nitrosative damage is involved in metallothionein prevention of diabetic cardiomyopathy. Diabetes 2005, 54:1829-1837

19. Wang J, Song Y, Elsherif L, Song Z, Zhou G, Prabhu SD, Saari JT, Cai $\mathrm{L}$ : Cardiac metallothionein induction plays the major role in the prevention of diabetic cardiomyopathy by zinc supplementation. Circulation 2006, 113:544-554

20. Wang Y, Feng W, Xue W, Tan Y, Hein DW, Li XK, Cai L: Inactivation of GSK-3beta by metallothionein prevents diabetes-related changes in cardiac energy metabolism, inflammation, nitrosative damage, and remodeling. Diabetes 2009, 58:1391-1402

21. Xue W, Liu Q, Cai L, Wang Z, Feng W: Stable overexpression of human metallothionein-IIA in a heart-derived cell line confers oxidative protection. Toxicol Lett 2009, 188:70-76

22. England K, O'Driscoll C, Cotter TG: Carbonylation of glycolytic proteins is a key response to drug-induced oxidative stress and apoptosis. Cell Death Differ 2004, 11:252-260

23. Wang Q, Donthi RV, Wang J, Lange AJ, Watson LJ, Jones SP, Epstein PN: Cardiac phosphatase-deficient 6-phosphofructo-2-kinase/fructose-2,6-bisphosphatase increases glycolysis, hypertrophy, and myocyte resistance to hypoxia. Am J Physiol Heart Circ Physiol 2008, 294:H2889-H2897

24. Livak KJ, Schmittgen TD: Analysis of relative gene expression data using real-time quantitative PCR and the 2(-Delta Delta C(T)) Method. Methods 2001, 25:402-408

25. Feng W, Ye F, Xue W, Zhou Z, Kang YJ: Copper regulation of hypoxia-inducible factor-1 activity. Mol Pharmacol 2009, 75:174-182

26. Feng W, Cai J, Pierce WM, Franklin RB, Maret W, Benz FW, Kang YJ: Metallothionein transfers zinc to mitochondrial aconitase through a direct interaction in mouse hearts. Biochem Biophys Res Commun 2005, 332:853-858

27. Gottlob K, Majewski N, Kennedy S, Kandel E, Robey RB, Hay N: Inhibition of early apoptotic events by Akt/PKB is dependent on the first committed step of glycolysis and mitochondrial hexokinase. Genes Dev 2001, 15:1406-1418

28. Agani F, Semenza GL: Mersalyl is a novel inducer of vascular endothelial growth factor gene expression and hypoxia-inducible factor 1 activity. Mol Pharmacol 1998, 54:749-754

29. Iyer NV, Kotch LE, Agani F, Leung SW, Laughner E, Wenger RH, Gassmann M, Gearhart JD, Lawler AM, Yu AY, Semenza GL: Cellular and developmental control of $\mathrm{O} 2$ homeostasis by hypoxia-inducible factor 1alpha. Genes Dev 1998, 12:149-162

30. Ryan HE, Lo J, Johnson RS: HIF-1 alpha is required for solid tumor formation and embryonic vascularization. EMBO J 1998, 17:30053015

31. Huang Y, Hickey RP, Yeh JL, Liu D, Dadak A, Young LH, Johnson RS, Giordano FJ: Cardiac myocyte-specific HIF-1alpha deletion alters vascularization, energy availability, calcium flux, and contractility in the normoxic heart. FASEB J 2004, 18:1138-1140

32. Depre C, Young ME, Ying J, Ahuja HS, Han Q, Garza N, Davies PJ, Taegtmeyer H: Streptozotocin-induced changes in cardiac gene expression in the absence of severe contractile dysfunction. J Mol Cell Cardiol 2000, 32:985-996

33. Stanley WC, Lopaschuk GD, McCormack JG: Regulation of energy substrate metabolism in the diabetic heart. Cardiovasc Res 1997, 34:25-33

34. Rodrigues B, McNeill JH: The diabetic heart: metabolic causes for the development of a cardiomyopathy. Cardiovasc Res 1992, 26:913922

35. Semenza GL: Perspectives on oxygen sensing. Cell 1999, 98:281284

36. Braithwaite SS, Palazuk B, Colca JR, Edwards CW III, Hofmann C: Reduced expression of hexokinase $\mathrm{II}$ in insulin-resistant diabetes. Diabetes 1995, 44:43-48

37. Belke DD, Larsen TS, Gibbs EM, Severson DL: Altered metabolism causes cardiac dysfunction in perfused hearts from diabetic $(\mathrm{db} / \mathrm{db})$ mice. Am J Physiol Endocrinol Metab 2000, 279:E1104-E1113

38. Noda C, Masuda T, Sato K, Ikeda K, Shimohama T, Matsuyama N Izumi T: Vanadate improves cardiac function and myocardial energy metabolism in diabetic rat hearts. Jpn Heart J 2003, 44:745-757

39. Ye G, Metreveli NS, Ren J, Epstein PN: Metallothionein prevents diabetes-induced deficits in cardiomyocytes by inhibiting reactive oxygen species production. Diabetes 2003, 52:777-783

40. Ye G, Metreveli NS, Donthi RV, Xia S, Xu M, Carlson EC, Epstein PN: Catalase protects cardiomyocyte function in models of type 1 and type 2 diabetes. Diabetes 2004, 53:1336-1343

41. Shiojima I, Sato K, Izumiya Y, Schiekofer S, Ito M, Liao R, Colucci WS, Walsh K: Disruption of coordinated cardiac hypertrophy and angiogenesis contributes to the transition to heart failure. J Clin Invest 2005, 115:2108-2118

42. Taniyama Y, Ito M, Sato K, Kuester C, Veit K, Tremp G, Liao R, Colucci WS, Ivashchenko Y, Walsh K, Shiojima I: Akt3 overexpression in the heart results in progression from adaptive to maladaptive hypertrophy. J Mol Cell Cardiol 2005, 38:375-385

43. Jiang Y, Reynolds C, Xiao C, Feng W, Zhou Z, Rodriguez W, Tyagi SC, Eaton JW, Saari JT, Kang YJ: Dietary copper supplementation reverses hypertrophic cardiomyopathy induced by chronic pressure overload in mice. J Exp Med 2007, 204:657-666

44. Zhou Y, Jiang Y, Kang YJ: Copper reverses cardiomyocyte hypertrophy through vascular endothelial growth factor-mediated reduction in the cell size. J Mol Cell Cardiol 2008, 45:106-117 